\title{
Mathematical Modelling of Double Chamber Microbial Fuel Cell using Homotopy Perturbation Method
}

\author{
P. Jeyabarathi, M. Kannan, L. Rajendran
}

\begin{abstract}
A theoretical model and simulation of a two-chamber microbial fuel cell are discussed. The model is generated through the integration of the microbial fuel cell's bio-electrochemical kinetics and balance of mass and charge. Several parameters are examined that have a direct impact on the performance of the microbial fuel cells. Approximate analytical expressions for the concentration of acetate, dissolved carbon dioxide, hydrogen ion,

biomass, dissolved oxygen, hydroxyl and cation $M^{+}$in microbial fuel cell and glucose and glutamic acid in GGA fuel cell are obtained by solving the non-linear equation using new the homotopy perturbation method. The analytical result is compared with the numerical results and satisfactory agreement is noted.
\end{abstract}

Keywords: Mathematical modeling, Microbial fuel cell, Artificial wastewater, Numerical simulation, Homotopy perturbation method.

\section{I.INTRODUCTION}

A typical microbial two-chamber fuel cell shares certain similarities with chemical fuel cells like direct methanol fuel cells (DMFCs)[1] and direct ascorbic acid fuel cells (DAAFCs)[2]. A cation-exchange membrane divides anodic and cathodic chambers in both cases, oxidizes fuels in the anodic chamber and releases protons that move through the membrane to enter the cathodic chamber. By integrating biochemical reactions, Picioreanu et al [3]create an acetate solution based on a biofilm model of a redox-mediated microbial fuel cell (MFC). Oliveira et al.[4] extended Zeng's model and developed a model explaining the microbial fuel cells thermodynamic conduct. Since the microbial fuel cell is a multi-phase system involving simultaneous biological and electrochemical processes, mass, charging and energy transfer, the creation of a mathematical model is essential to the design and optimization of this type of cell. Zeng et al.[5 ] and Dannys et al.[6 ] present a one-dimensional model representing a two-chamber microbial fuel cell using an acetate substratum dependent expression of ButlerVolmer and mass/charge balances. The model of acetate was then extended to glucose and glutamic acid (GGA), confirming that it is indeed possible to extend the model to multiple substrates. Other than an acetate-fuelled microbial

Revised Manuscript Received on February 05, 2020.

* Correspondence Author

P. Jeyabarathi*, Department of Mathematics, AMET, Deemed to be University, Chennai 603-112, India,Email:bsc.jeya@yahoo.com

M. Kannan, Depatment of Mathematics, Government Arts College, Ariyalur, Affiliated to Bharathidasan University,Thiruchirappalli, India,Email: kannan5018@gmail.com.

L. Rajendran, Department of Mathematics, AMET, Deemed to be University, Chennai 603-112, India,Email: raj_sms@rediffmail.com

(C) The Authors. Published by Blue Eyes Intelligence Engineering and Sciences Publication (BEIESP). This is an open access article under the CC BY-NC-ND license (http://creativecommons.org/licenses/by-nc-nd/4.0/) fuel cell, the current method is also successfully applied tothe use of artificial wastewater (glucose and glutamic acid solution) as fuel. In this paper, for all values of parameters, analytical expressions of the concentration of acetate, dissolved carbon dioxide, hydrogen ion, biomass, dissolved oxygen, hydroxyl, and cation $M^{+}$are in Microbial fuel cell and Glucose and glutamic acid in GGA fuel cell is obtained by solving the non-linear equations using the homotopy perturbation method.

Nomenclature

\begin{tabular}{|c|c|c|c|}
\hline Symbols & meanings & Value & Units \\
\hline $\begin{array}{l}C_{A C}, C_{C_{2}}, \\
C_{H}, X\end{array}$ & $\begin{array}{l}\text { Concentration of } \\
\text { acetate, dissolved } \\
\mathrm{CO}_{2} \text {,hydrogen ion, } \\
\text { biomass in anode } \\
\text { components }\end{array}$ & - & $\mathrm{mol} \mathrm{m} \mathrm{m}^{-3}$ \\
\hline $\begin{array}{l}C_{\mathrm{O}_{2}}, C_{\mathrm{OH}} \\
C_{M}\end{array}$ & $\begin{array}{l}\text { Concentration of } \\
\text { dissolved } \mathrm{O}_{2} \text {, } \\
\text { hydroxyl, cation } \mathrm{M}^{+} \text {in } \\
\text { cathode components }\end{array}$ & - & $\mathrm{mol} \mathrm{m} \mathrm{m}^{-3}$ \\
\hline$C_{6}, C_{5}$ & $\begin{array}{l}\text { Concentration of } \\
\text { glucose, glutamic acid } \\
\text { in GGA MFC }\end{array}$ & - & $\mathrm{mol} \mathrm{m}^{-3}$ \\
\hline $\begin{array}{l}C_{A C . i n}, C_{C O_{2 . i n}} \\
C_{H . i n}, X_{i n}\end{array}$ & $\begin{array}{l}\text { Initial concentration of } \\
\text { acetate, dissolved } \\
\mathrm{CO}_{2} \text {,hydrogen ion, } \\
\text { biomass in anode } \\
\text { components }\end{array}$ & 1 & $\mathrm{~mol} \mathrm{~m}^{-3}$ \\
\hline $\begin{array}{l}C_{\mathrm{O}_{2} \text {.in }}, C_{\mathrm{OH} . \mathrm{in}} \\
C_{\text {M.in }}\end{array}$ & $\begin{array}{l}\text { Initial concentration of } \\
\text { dissolved } \mathrm{O}_{2} \text {, } \\
\text { hydroxyl, cation } M^{+}\end{array}$ & 1 & $\mathrm{~mol} \mathrm{~m}^{-3}$ \\
\hline$C_{6 . i n}, C_{5 . i n}$ & $\begin{array}{l}\text { Initial concentration of } \\
\text { glucose and glutamic } \\
\text { acid in GGA MFC }\end{array}$ & 1 & $\mathrm{~mol} \mathrm{~m}^{-3}$ \\
\hline
\end{tabular}


Mathematical Modelling of Double Chamber Microbial Fuel Cell using Homotopy Perturbation Method

\begin{tabular}{|c|c|c|c|}
\hline $\begin{array}{l}C_{A C}^{i n}, C_{C O_{2}}^{i n}, \\
C_{H}^{i n}, X^{i n}\end{array}$ & $\begin{array}{l}\text { Concentration of } \\
\text { acetate, dissolved } \\
\text { carbon dioxide, } \\
\text { hydrogen ion, bacteria } \\
\text { in the influent of anode } \\
\text { compartment }\end{array}$ & $1.56,1,1,1$ & $\mathrm{~mol} \mathrm{~m}^{-3}$ \\
\hline $\begin{array}{l}C_{O_{2}}^{i n}, C_{M}^{i n} \\
C_{O H}^{i n}\end{array}$ & $\begin{array}{l}\text { Concentration of } \\
\text { dissolved oxygen, } \mathrm{M}^{+} \text {, } \\
\mathrm{OH}^{-} \text {in the influent of } \\
\text { cathode compartment. }\end{array}$ & $0.312,1,1$ & mol $m^{-3}$ \\
\hline$C_{6}^{i n}, C_{5}^{i n}$ & $\begin{array}{l}\text { Concentration of } \\
\text { glucose, glutamic acid } \\
\text { in the influent of anode } \\
\text { compartment }\end{array}$ & $1.2,15$ & $m o l m^{-3}$ \\
\hline$F$ & Faraday's constant & 96485.4 & $\begin{array}{l}\text { Coulombs } \\
\text { mol }^{-1}\end{array}$ \\
\hline$R$ & Gas constant & 8.3144 & $J \mathrm{~mol}^{-1} \mathrm{~K}^{-1}$ \\
\hline$T$ & Temperature & 303 & $K$ \\
\hline$k^{m}, k^{a q}$ & $\begin{array}{l}\text { Electrical conductivity } \\
\text { of membrane and } \\
\text { aqueous solution. }\end{array}$ & 0.017 & $\mathrm{Ohm}^{-1} \mathrm{~m}^{-1}$ \\
\hline$d^{\text {cell }}, d^{m}$ & $\begin{array}{l}\text { Distance between } \\
\text { anode and cathode in } \\
\text { the cell and thickness. }\end{array}$ & $0.777,0.2$ & $m$ \\
\hline$C_{a}, C_{c}$ & $\begin{array}{l}\text { Capacitance of anode } \\
\text { and cathode }\end{array}$ & 500,400 & $\mathrm{Fm}^{-2}$ \\
\hline$V_{a}, V_{c}$ & $\begin{array}{l}\text { Volume of anode and } \\
\text { cathode compartment }\end{array}$ & 0.00001 & $F m^{-2}$ \\
\hline$Q_{a}, Q_{C}$ & $\begin{array}{l}\text { Flow rate of fuel feed } \\
\text { to anode and cathode }\end{array}$ & $\begin{array}{l}0.00001 \\
0.00002\end{array}$ & $m^{3} h^{-1}$ \\
\hline$f_{x}$ & $\begin{array}{l}\text { Reciprocal of wash-out } \\
\text { fraction }\end{array}$ & 10 & None \\
\hline$k_{1}^{0}, k_{2}^{0}$ & $\begin{array}{l}\text { Rate constant of anode } \\
\text { and cathode reaction }\end{array}$ & $0.2,0.004$ & $\begin{array}{l}\operatorname{molm}^{-2} h^{-1} \\
m o \Gamma^{4} m^{12} h^{-1}\end{array}$ \\
\hline$K_{A C}, K_{O_{2}}$ & $\begin{array}{l}\text { Rate constant for } \\
\text { acetate and dissolved } \\
\text { oxygen }\end{array}$ & $0.05,0.004$ & $\mathrm{~mol} \mathrm{~m}^{-3}$ \\
\hline$\alpha, \alpha_{1}, \alpha_{2}$ and $\beta$ & $\begin{array}{l}\text { Charge transfer } \\
\text { coefficient of glucose } \\
\text { and glutamic acid at } \\
\text { anode and cathode. }\end{array}$ & $\begin{array}{l}0.051,0.76 \\
0.74,0.663\end{array}$ & None \\
\hline$U_{\text {cell }}$ & Cell voltage & - & Volt \\
\hline$U^{0}$ & $\begin{array}{l}\text { Cell open circuit } \\
\text { potential }\end{array}$ & 0.77 & Volt \\
\hline$Y_{a c}$ & yield & 0.05 & None \\
\hline$A_{m}$ & Area of membrane & 0.0002 & $m^{2}$ \\
\hline$k_{\text {dec }}$ & $\begin{array}{l}\text { Decay constant for } \\
\text { acetate utilisers }\end{array}$ & 0.08 & $h^{-1}$ \\
\hline$\eta_{a}, \eta_{c}$ & $\begin{array}{l}\text { Overpotential at the } \\
\text { anode and cathode }\end{array}$ & - & V \\
\hline
\end{tabular}

\begin{tabular}{|l|l|l|l|}
\hline$i_{\text {cell }}$ & Cell current density & 4.8 & $\mathrm{Am}^{-2}$ \\
\hline$N_{M}$ & Flux of $M^{+}$ions & - & $\mathrm{molm}^{-2} \mathrm{~h}^{-1}$ \\
\hline
\end{tabular}

\section{MATHEMATICAL FORMULATION OF THE PROBLEM.}

The reaction scheme of the anode, cathode chamber in microbial fuel cell and glucose and glutamic acid in GGA fuel cell [5] is

$$
\begin{aligned}
& \left(\mathrm{CH}_{2} \mathrm{O}\right)_{2}+2 \mathrm{H}_{2} \mathrm{O} \rightarrow 2 \mathrm{CO}_{2}+8 \mathrm{H}^{+}+8 e^{-1} \\
& \mathrm{O}_{2}+4 e^{-}+2 \mathrm{H}_{2} \mathrm{O} \rightarrow 4 \mathrm{OH}^{-} \\
& \mathrm{C}_{6 \mathrm{H}_{12}} \mathrm{O}_{6}+6 \mathrm{H}_{2} \mathrm{O} \rightarrow 6 \mathrm{CO}_{2}+24 \mathrm{H}^{+}+24 e^{-} \\
& \mathrm{C}_{5} \mathrm{H}_{9} \mathrm{NO}_{4}+6 \mathrm{H}_{2} \mathrm{O} \rightarrow 5 \mathrm{CO}_{2}+\mathrm{NH}_{4}^{+}+17 \mathrm{H}^{+}+18 e^{-1}
\end{aligned}
$$

\section{II(A). MASS BALANCES FOR ANODE COMPARTMENT [5]}

The mass balances of the four components in the anode compartments namely, acetate,

dissolved $\mathrm{CO}_{2}$, hydrogen ion and biomass are expressed by Eqns. (5-8).

$$
\begin{aligned}
& V_{a} \frac{d C_{A C}}{d t}=Q_{a}\left(C_{A C}^{i n}-C_{A C}\right)-A_{m} r_{1} \\
& V_{a} \frac{d C_{C O_{2}}}{d t}=Q_{a}\left(C_{C O_{2}}^{i n}-C_{C_{2}}\right)+2 A_{m} r_{1} \\
& V_{a} \frac{d C_{H}}{d t}=Q_{a}\left(C_{H}^{i n}-C_{H}\right)+8 A_{m} r_{1} \\
& V_{a} \frac{d X}{d t}=\frac{Q_{a}\left(X^{i n}-X\right)}{f_{X}}+A_{m} Y_{a c} r_{1}-V_{a} K_{d e c} X
\end{aligned}
$$

The initial conditions are

$$
C_{A C}=C_{A C_{\text {in }}}, C_{C_{2}}=C_{C_{2 i n}}, C_{H}=C_{H_{\text {in }}}, X=X_{\text {in }} \text { at } \quad t=0
$$

where $V, Q$ and $A_{m}$ are the volume of the anode and cathode compartment, $Y_{a c}$ the bacterial yield, and $K_{d e c}$ the decay constant for acetate utilizes, $f_{x}$ the reciprocal of the washout fraction, $C_{A C}, C_{\mathrm{CO}_{2}}, C_{H}$ and $X$ are concentration of acetate, dissolved $\mathrm{CO}_{2}$, hydrogen ion and biomass.

\section{II(B). MASS BALANCES FOR CATHODE COMPARTMENT [5]}

The mass balances of the three components in the cathode compartments namely, dissolved $\mathrm{O}_{2}$, hydroxyl and cation $\mathrm{M}^{+}$are expressed by Eqns.

(10-13).

$V_{C} \frac{d C_{O_{2}}}{d t}=Q_{c}\left(C_{O_{2}}^{i n}-C_{O_{2}}\right)+r_{2} A_{m}$

$V_{C} \frac{d C_{\mathrm{OH}}}{d t}=Q_{C}\left(C_{\mathrm{OH}}^{i n}-C_{\mathrm{OH}}\right)-4 r_{2} A_{m}$

$V_{C} \frac{d C_{M}}{d t}=Q_{c}\left(C_{M}^{i n}-C_{M}\right)+N_{M} A_{m}$

The initial conditions are

$C_{\mathrm{O}_{2}}=C_{\mathrm{O}_{2 i n}}, C_{\mathrm{OH}}=C_{\mathrm{OH}_{\text {in }}}, C_{M}=C_{M_{\text {in }}}$ at $t=0$

where $N_{M}=\frac{3600 i_{\text {cell }}}{F}$ is the flux of $M^{+}$ions, $i_{\text {cell }}$ is the cell current density, $\mathrm{C}_{\mathrm{O}_{2}}, \mathrm{C}_{\mathrm{OH}}$ 
and $C_{M}$ are the concentration of dissolved ${ }^{O_{2}}$,hydroxyl, and $M^{+}$. By using Butler-Volmer equation [7] which is shown in the following equation:

$r_{1}=k_{1}^{0} \frac{C_{A C}}{K_{A C}+C_{A C}} X \exp \left(\frac{\alpha F}{R T} \eta_{a}\right)$

$r_{2}=-k_{2}^{0} \frac{C_{O_{2}}}{K_{O_{2}}+C_{O_{2}}} \exp \left(\frac{(\beta-1) F}{R T} \eta_{C}\right)$

where $k_{1}^{0}, k_{2}^{0}$ are rate constants of anode and cathode reaction, ${ }^{K_{A C}}$ and ${ }^{K_{O_{2}}}$ are half velocity rate constant for acetate and dissolved oxygen. $\eta_{a}, \eta_{C}$ is the over potential at the anode and cathode, $\alpha$ and $\beta$ is the charge transfer coefficient of the anodic and cathodic reaction. $R$ is the gas constant, $F$ is the faraday constant and $T$ is the temperature.

\section{II(C). MASS BALANCES FOR ANODE COMPARTMENTS IN THE GGA FUEL CELL [5].}

The mass balances of the five components in the anode compartments namely, glucose, glutamic acid , dissolved $\mathrm{CO}_{2}$,hydrogen ion and biomass are expressed by Eqns. (1621).

$V_{a} \frac{d C_{6}}{d t}=Q_{a}\left(C_{6}^{i n}-C_{6}\right)-A_{m} r_{11}$

$V_{a} \frac{d C_{5}}{d t}=Q_{a}\left(C_{5}^{i n}-C_{5}\right)-A_{m} r_{12}$

$V_{a} \frac{d C_{\mathrm{CO}_{2}}}{d t}=Q_{a}\left(C_{\mathrm{CO}_{2}}^{i n}-C_{\mathrm{CO}_{2}}\right)+6 A_{m} r_{11}+5 A_{m} r_{12}$

$V_{a} \frac{d C_{H}}{d t}=Q_{a}\left(C_{H}^{i n}-C_{H}\right)+24 A_{m} r_{11}+17 A_{m} r_{12}$

$V_{a} \frac{d X}{d t}=Q_{a} \frac{\left(X^{i n}-X\right)}{f_{X}}+A_{m} Y_{A W}\left(r_{11}+r_{12}\right)-V_{a} K_{d A W} A_{m} r_{12}$

The initial conditions are

$C_{6}=C_{6_{\text {in }}}, C_{5}=C_{5_{\text {in }}}, C_{C_{2}}=C_{C_{2 i n}}, C_{H}=C_{H_{\text {in }}}, X=X_{\text {in }}$ at $t=0$ (21)

where $Y_{A W}$ the bacterial yield, $C_{6}$ and $C_{5}$ are the concentration of glucose and glutamic acid respectively. By using Butler-Volmer equation [7] which is shown in the following equation:

$r_{11}=k_{11}^{0} \frac{C_{6}}{K_{6}+C_{6}} X \exp \left(\frac{\alpha_{1} F}{R T} \eta_{a}\right)$

$r_{12}=k_{12}^{0} \frac{C_{5}}{K_{5}+C 5} X \exp \left(\frac{\alpha_{2} F}{R T} \eta_{a}\right)$

where $k_{11}^{0}$ and $k_{12}^{0}$ rate constants of glucose and glutamic acid, ${ }^{\alpha_{1}}$ and ${ }^{\alpha_{2}}$ are charge transfer coefficient of glucose and glutamic acid.

II(D). The charge balances at the anode and cathode [5]

The charge balance of the anode and cathode are given by the following Eqns. (24-25)

$C_{a} \frac{d \eta_{a}}{d t}=3600 i_{c e l l}-8 F r_{1}$

$C_{C} \frac{d \eta_{C}}{d t}=-3600 i_{c e l l}-8 F r_{2}$

The initial conditions are

Published By:

Blue Eyes Intelligence Engineering \& Sciences Publication where $C_{a}$ and $C_{c}$ are the capacitances of anode and cathode. The cell voltage $U_{\text {cell }}$ is calculated as

$$
U_{\text {cell }}=U^{0}-\eta_{a}+\eta_{c}-\left(\frac{d^{m}}{k^{m}}+\frac{d_{c e l l}}{k^{a q}}\right) i_{c e l l}
$$

where $U^{0}$ is the open circuit voltage, $d^{m}, d_{\text {cell }}$ are thickness, $k^{m}$ and $k^{a q}$ are the conductivities of the membrane. The steady state condition for acetate

$C_{A C}(t)=C_{A C}^{i n}-450 i_{\text {cell }} \frac{A_{m}}{F Q_{a}}$ where $r_{1}=\frac{450 i_{c e l l}}{F}$

\section{ANALYTICAL EXPRESSION OF CONCENTRATION USING HOMOTOPY PERTURBATION METHOD.}

Recently, many authors applied the HPM to solve the various linear and nonlinear problems in physics and engineering sciences [8-10]. Suganya and Rajendran [11] derived the analytical solution of nonlinear equations in microbial fuel cells in wastewater treatment using the homotopy perturbation method. in this paper, the concentrations of acetate, dissolved carbon dioxide, hydrogen ion, biomass, dissolved oxygen, hydroxyl, and cation $\mathrm{M}^{+}$are in microbial fuel cell and glucose, and glutamic acid in GGA fuel cell can be obtained by solving Eqns. ((5-8),(10-12) and (16-20)) using HPM (see Appendix A) Eqn. (5) can be rewritten $\frac{d C_{A C}}{d t}=A_{1}-A_{2}\left(\frac{C_{A C}}{k_{A C}+C_{A C}}\right)$ where

$A_{1}=\frac{Q_{a} C_{A C}^{i n}}{V_{a}}-\frac{Q_{a} C_{A C . i n}}{V_{a}}, A_{2}=\frac{A_{m} k_{1}^{0} X_{i n} e^{\left(\frac{\alpha F}{R T} \eta_{a . i n}\right)}}{V_{a}}$

for some fixed experimental values of the parameter $Q_{a}=0.00002, V_{a}=0.00005, C_{A C}^{i n}=1.56, C_{A C . i n}=1, X_{i n}=1$,

$A_{m}=0.0005, k_{1}^{0}=0.207, F=964854, K_{A C}=0.592, \eta_{\text {a.in }}=0.1$.

Solving the above equation we get

$C_{A C}(t)=0.067+0.67 W\left(5.8 e^{-2.7 t}\right)$ where $A_{1}=0.2, A_{2}=2, \alpha=0.01$

$$
C_{A C}(t)=0.052+0.65 W\left(6.2 e^{-3.5 t}\right)
$$

where

$A_{1}=0.2, A_{2}=3, \alpha=0.051$

$C_{A C}(t)=0.018+0.62 W\left(7.8 e^{-11 t}\right)$ where $A_{1}=0.2, A_{2}=7, \alpha=0.3$ 
$C_{A C}(t)=0.002+0.6 W\left(8.7 e^{-107.7 t}\right)$ where $A_{1}=0.2, A_{2}=65, \alpha=0.9$

$$
\begin{gathered}
C_{\mathrm{CO}_{2}}(t)=A_{3} \frac{Q_{a}}{V_{a}}+\left(C_{C_{2} . i n}-A_{3} \frac{Q_{a}}{V_{a}}\right) e^{-\frac{Q_{a} t}{V_{a}}} \text { where } \\
A_{3}=\frac{Q_{a} C_{C O_{2}}^{i n}}{V_{a}}+\frac{2 k_{1}^{0} A_{m} C_{A C . i n} X_{i n} e^{\left(\frac{\alpha F \eta_{a . i n}}{R T}\right)}}{V_{a}\left(K_{A C}+C_{A C . i n}\right)}
\end{gathered}
$$$$
C_{H}(t)=A_{4} \frac{Q_{a}}{V_{a}}+\left(C_{H . i n}-A_{4} \frac{Q_{a}}{V_{a}}\right) e^{-\frac{Q_{a} t}{V_{a}}} \text { where }
$$$$
A_{4}=\frac{Q_{a} C_{H}^{i n}}{V_{a}}+\frac{8 k_{1}^{0} A_{m} C_{A C . i n} X_{i n} e^{\left(\frac{\alpha F \eta_{a . i n \cdot}}{R T}\right)}}{V_{a}\left(K_{A C}+C_{A C . i n}\right)}
$$$$
X(t)=\frac{-Q_{a} X^{i n}}{A_{5} f_{X} V_{a}}+\left(X_{\text {in }}+\frac{Q_{a} X^{i n}}{A_{5} f_{X} V_{a}}\right) e^{-A_{5} t} \text { where }
$$$$
A_{5}=\frac{-Q_{a}}{f_{x} V_{a}}+\frac{A_{m} Y_{a c} k_{1}^{0} e^{\left(\frac{\alpha F \eta_{a . i n}}{R T}\right)} C_{A C . i n}}{V_{a}\left(K_{A C}+C_{A C . i n}\right)}-K_{d e c}
$$$$
C_{O_{2}}(t)=\frac{Q_{c} C_{O_{2}}^{i n}}{V_{c}}+\left(C_{O_{2 . i n}}-\frac{Q_{c} C_{O_{2}}^{i n}}{V_{c}}\right) e^{-A_{6} t} \text { where }
$$$$
A_{6}=\frac{Q_{C}}{V_{c}}+\frac{A_{m} k_{2}^{0} e^{\left(\frac{(\beta-1) F \eta_{c . i n}}{R T}\right)}}{V_{c}\left(K_{O_{2}}+C_{O_{2 . i n}}\right)}
$$$$
C_{\mathrm{OH}}(t)=A_{7} \frac{Q_{C}}{V_{C}}+\left(C_{\mathrm{OH} \text {.in }}-A_{7} \frac{Q_{C}}{V_{C}}\right) e^{\frac{-Q_{C} t}{V_{C}}} \text { where }
$$$$
A_{7}=\frac{Q_{C} C_{O H}^{i n}}{V_{c}}+\frac{4 k_{2}^{0} A_{m} C_{O_{2 . i n}} e^{\frac{(\beta-1) F \eta_{c . i n}}{R T}}}{V_{c}\left(K_{O_{2}}+C_{O_{2} . i n}\right)}
$$$$
C_{M}(t)=A_{8} \frac{Q_{C}}{V_{c}}+\left(C_{M . i n}-A_{8} \frac{Q_{C}}{V_{c}}\right) e^{\frac{-Q_{C} t}{V_{C}}} \text { where }
$$$$
A_{8}=\frac{Q_{c} C_{M}^{i n}}{V_{c}}+\frac{3600 i_{c e l l} A_{m}}{V_{c} F}
$$

\section{III(A). ANALYTICAL EXPRESSION OF GGA MICROBIAL FUEL CELLS CONCENTRATION USING HOMOTOPY PERTURBATION METHOD.}

Equation (16) can be rewritten $\frac{d C_{6}}{d t}=A_{9}-A_{10}\left(\frac{C_{6}}{K_{6}+C_{6}}\right)$ where $A_{9}=\frac{Q_{a} C_{6}^{i n}}{V_{a}}-\frac{Q_{a} C_{6 . i n}}{V_{a}}, A_{10}=\frac{A_{m} k_{11}^{0} X_{i n} e^{\left(\frac{\alpha_{1} F}{R T} \eta_{a . i n}\right)}}{V_{a}}$ for some fixed experimental values of parameter $Q_{a}=0.00002, V_{a}=0.00005, C_{6}^{i n}=1.2, C_{6 . i n}=1, X_{i n}=1$,

$A_{m}=0.0005, k_{11}^{0}=0.005, K_{6}=0.3, F=964854, \eta_{\text {a.in }}=0.1$.

Solving the above equation we get

$C_{6}(t)=0.038+0.336 w\left(49.4 e^{-1.9 t}\right)$ where

$A_{9}=0.08, A_{10}=0.72, \alpha_{1}=0.1$

$C_{6}(t)=0.012+0.316 w\left(70.3 e^{-4.8 t}\right)$ where

$A_{9}=0.08, A_{10}=1.6, \alpha_{1}=0.3$

$C_{6}(t)=0.007+0.306 W\left(81.5 e^{-10.5 t}\right)$ where

$A_{9}=0.08, A_{10}=3.3, \alpha_{1}=0.5$

$C_{6}(t)=0.005+0.30 w\left(85.1 e^{-46.4 t}\right)$ where

$A_{9}=0.08, A_{10}=4.8, \alpha_{1}=0.6$

Equation (17) can be rewritten $\frac{d C_{5}}{d t}=A_{11}-A_{12}\left(\frac{C_{5}}{K_{5}+C_{5}}\right)$ where

$A_{11}=\frac{Q_{a} C_{5}^{i n}}{V_{a}}-\frac{Q_{a} C_{5 . i n}}{V_{a}}, A_{12}=\frac{A_{m} k_{12}^{0} X_{i n} e^{\left(\frac{\alpha_{2} F}{R T} \eta_{a}\right)}}{V_{a}}$

for some fixed experimental values of parameter

$Q_{a}=0.00002, V_{a}=0.00005, C_{5}^{i n}=1.15, C_{5 . i n}=1, X_{i n}=1$,

$A_{m}=0.0005, k_{12}^{0}=0.0007, K_{5}=0.1, F=964854, \eta_{a_{\text {. in }}}=0.1$.

Solving the above equation we get

$C_{5}(t)=0.007+0.107 W\left(10475 e^{-15.7 t}\right)$ where

$A_{11}=0.06, A_{12}=0.98, \alpha_{2}=0.7$

$C_{5}(t)=0.015+0.115 W\left(44933 e^{-3.48 t}\right)$ where

$A_{11}=0.06, A_{12}=0.46, \alpha_{2}=0.5$

(50)

$C_{5}(t)=0.04+0.14 W\left(6518.72 e^{-1.07 t}\right) \quad$ where $A_{11}=0.06, A_{12}=0.21, \alpha_{2}=0.2$

$C_{C_{2}}(t)=A_{13} \frac{Q_{a}}{V_{a}}+\left(C_{C_{2}, i n}-A_{13} \frac{Q_{a}}{V_{a}}\right) e^{-\frac{Q_{a} t}{V_{a}}}$ where

$A_{13}=\frac{Q_{a} C_{C O_{2}}^{i n}}{V_{a}}+\frac{A_{m} X_{\text {in }}}{V_{a}}\left(\frac{6 k_{11}^{0} C_{6 . i n} e^{\frac{\alpha_{1} F \eta_{a}}{R T}}}{K_{6}+C_{6 . i n}}+\frac{5 k_{12}^{0} C_{5 . i n} e^{\frac{\alpha_{2} F \eta_{a}}{R T}}}{K_{5}+C_{5 . i n}}\right)$

$C_{H}(t)=A_{14} \frac{Q_{a}}{V_{a}}+\left(C_{C_{2}, i n}-A_{14} \frac{Q_{a}}{V_{a}}\right) e^{-\frac{Q_{a} t}{V_{a}}}$ where

$A_{14}=\frac{Q_{a} C_{H}^{i n}}{V_{a}}+\frac{A_{m} X_{i n}}{V_{a}}\left(\frac{24 k_{11}^{0} C_{6 . i n} e^{\frac{\alpha_{1} F \eta_{a . i n .}}{R T}}}{K_{6}+C_{6 . i n}}+\frac{17 k_{12}^{0} C_{5 . i n} e^{\frac{\alpha_{2} F \eta_{a . i n}}{R T}}}{K_{5}+C_{5 . i n}}\right)$ 


$$
\begin{aligned}
& X(t)=\frac{-Q_{a}}{A_{15} f_{X} V_{a}} X^{i n}+\left(X_{i n}+\frac{Q_{a}}{A_{15} V_{a} f_{X}} X^{i n}\right) e^{A_{15} t} \text { where } \\
& A_{15}=-\frac{Q_{a}}{V_{a} f_{x}}+\frac{A_{m} Y_{A W}}{V_{a}}\left(\frac{k_{11}^{0} C_{6 . i n} e^{\frac{\alpha_{1} F \eta_{a . i n}}{R T}}}{K_{6}+C_{6 . i n}}+\frac{k_{12}^{0} C_{5 . i n} e^{\frac{\alpha_{2} F \eta_{a . i n}}{R T}}}{K_{5}+C_{5 . i n}}\right)-K_{\text {dAW }}
\end{aligned}
$$

\section{III(B). ANALYTICAL EXPRESSION OF OVER POTENTIAL AT THE ANODE AND CATHODE USING HOMOTOPY PERTURBATION METHOD.}

Eqn. (24) can be rewritten

$\frac{d \eta_{a}}{d t}=B_{1}-B_{2} e^{B_{3} \eta_{a}(t)}$ where

$$
B_{1}=\frac{3600 i_{\text {cell }}}{C_{a}}, B_{2}=\frac{8 F k_{1}^{0} C_{A C . i n} X_{\text {in }}}{C_{a}\left(K_{A C}+C_{A C . i n}\right)}, B_{3}=\frac{\alpha F}{R T}
$$

Solving the above equation we get

$\eta_{a}(t)=-\frac{1}{B_{3}} \log \left(\frac{e^{-B_{3}\left(B_{1} t+\eta_{\text {ain }}\right)}\left[B_{2} e^{B_{3} \eta_{\text {ain }}}\left(e^{B_{1} B_{3} t}-1\right)+B_{1}\right]}{B_{1}}\right)$

Eqn. (25) can be rewritten

$$
\begin{aligned}
\frac{d \eta_{c}}{d t} & =-B_{4}-B_{5} e^{B_{6}} \eta_{c}(t) \text { where } \\
B_{4} & =\frac{3600 i_{c e l l}}{C_{C}}, B_{5}=\frac{-4 F k_{2}^{0} C_{O_{2} . i n}}{C_{c}\left(K_{O_{2}}+C_{O_{2} . i n}\right)}, B_{6}=\frac{(\beta-1) F}{R T}
\end{aligned}
$$

Solving the above equation we get

$$
\eta_{C}(t)=\frac{-1}{B_{6}} \log \left(\frac{e^{B_{4} B_{6} t}\left[B_{4} e^{-B_{6} \eta_{c . i n}}-B_{5}\right]+B_{5}}{B_{4}}\right)
$$

Using Eqns. (56) and (58), the Eqn. (27) becomes

$$
\begin{aligned}
U_{\text {cell }} & =\frac{1}{B_{3}} \log \left(\frac{e^{-B_{3}\left(B_{1} t+\eta a_{\text {in }}\right)}\left[B_{2} e^{B_{3} \eta \text { in }}\left(e^{B_{1} B_{3} t}-1\right)+B_{1}\right]}{B_{1}}\right) \\
& -\frac{1}{B_{6}} \log \left(\frac{e^{B 4} B_{6} t\left[B_{4} e^{-B 6 \eta \text { c.in }}-B_{5}\right]+B_{5}}{B_{4}}\right)+U^{0}-\left(\frac{d^{m}}{k^{m}}-\frac{d_{\text {cell }}}{k^{q q}}\right) i_{\text {cell }}
\end{aligned}
$$

\section{NUMERICAL SIMULATION}

Numerically, the non-linear Eqns.( (5-8)and (10-12)) in Microbial fuel cells and Eqns. (16-20) in GGA Fuel cells are solved for the initial condition (equations (9),(13) and (21)). For ordinary differential equations, the function of ode 45 in

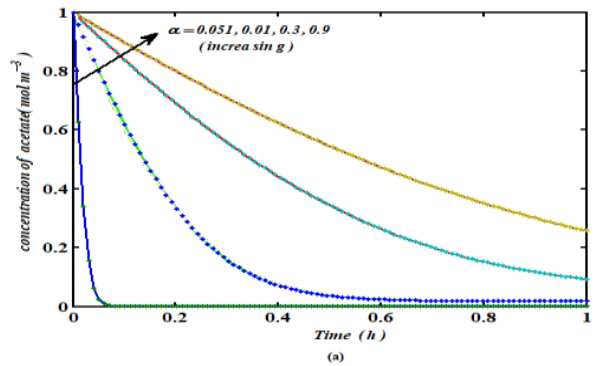

the Matlab program is used to solving the boundary value problems. The numerical results for all parameter values are also compared to the analytical expressions equations obtained (29-54).

\section{DISCUSSION}

Eqns. (31-34) represents the concentration of acetate for various experimental values of parameters. Fig. 1(a) represents the concentration of acetate versus time for the various value of the decay constant for acetate utilisers $k_{d e c}$. From the figure it is inferred that the concentration of acetate is the decreasing function. The concentration of dissolved carbon dioxide, hydrogen ion, and biomass versus time are represented in Fig. 1(b-d). From the figure, it is observed that dissolved carbon dioxide, hydrogen ion, and biomass are increase when time increases.

Fig .2 represents a concentration of dissolved oxygen, hydroxyl, and $M^{+}$versus time for the various values of charge transfer coefficient of cathode $\beta$, rate constant of dissolved oxygen $\mathrm{K}_{\mathrm{O}_{2}}$, and volume of cathode ${ }^{V_{c}}$. From the figure, it is inferred that concentration dissolved oxygen , increases when time increases. From the figure it is observed that the concentration of hydroxyl, and $\mathrm{M}^{+}$is the decreasing function. Fig. 3 represents the concentration of glucose, glutamic acid, dissolved ${ }^{\mathrm{CO}_{2}}$, hydrogen ion, and biomass for various values of parameters. From the figure, it is noted that glucose, glutamic acid, dissolved $\mathrm{CO}_{2}$, hydrogen ion, and biomass are decreasing function.

Cell voltage $U_{\text {cell }}$ versus time is represented that Fig. 4 for the various values of parameters. From the figure, it is observed that cell voltage increases when time increases and reaches the steady-state value when $t=10$ hour approximately.

Fig. 5 represents cell current density $i_{c e l l}$ versus time for various values of parameters feed flow rate of anode $Q_{a}$ and area of membrane ${ }^{A_{m}}$. From the figure, it is inferred that cell current density $i_{\text {cell }}$ increases when time increases and reaches the steady-state when $t=1$ hour for all values of other parameters. The maximum value of cell current density depends upon $Q_{a}$ and $A_{m}$

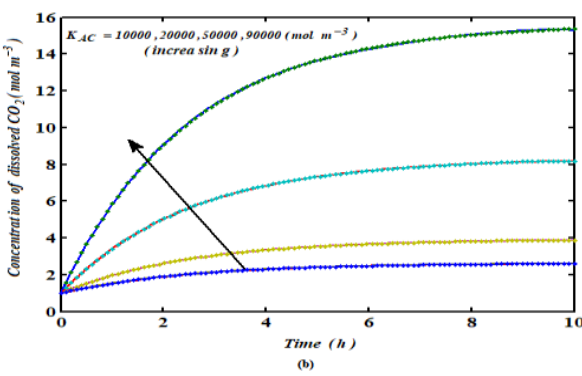

Published By:

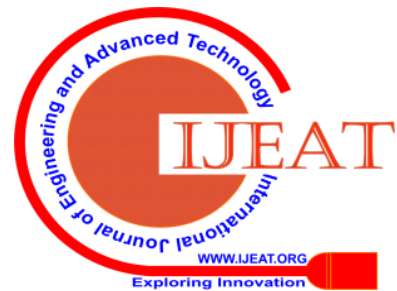



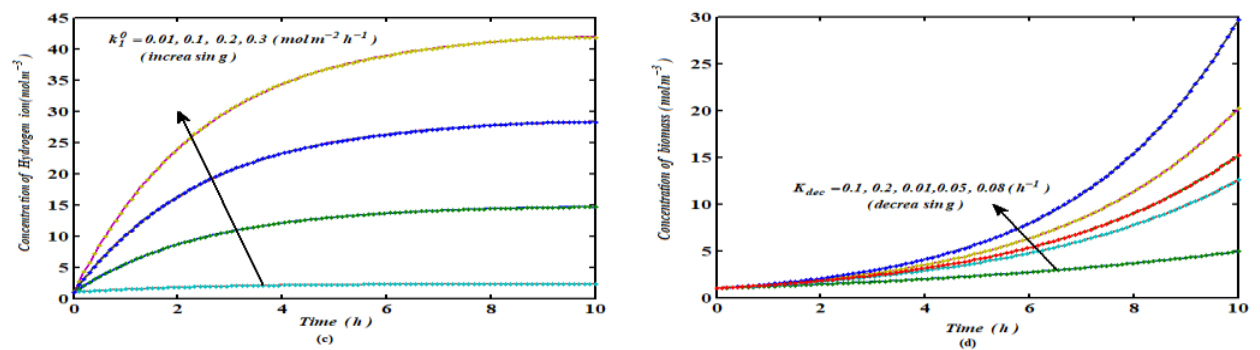

Fig.1 Comparison of analytical and numerical solutions of anode compartment in Microbial fuel cell.

(a) Concentration of acetate versus time (Eqns.(31-34))

(b) Concentration of dissolved $\mathrm{CO}_{2}$ versus time (Eqn. (35))

(c) Concentration of hydrogen ion versus time (Eqn. (36))

(d) Concentration of biomass versus time (Eqn. (37))

Solid lines represent the numerical simulation and the dotted lines represent the analytical solutions
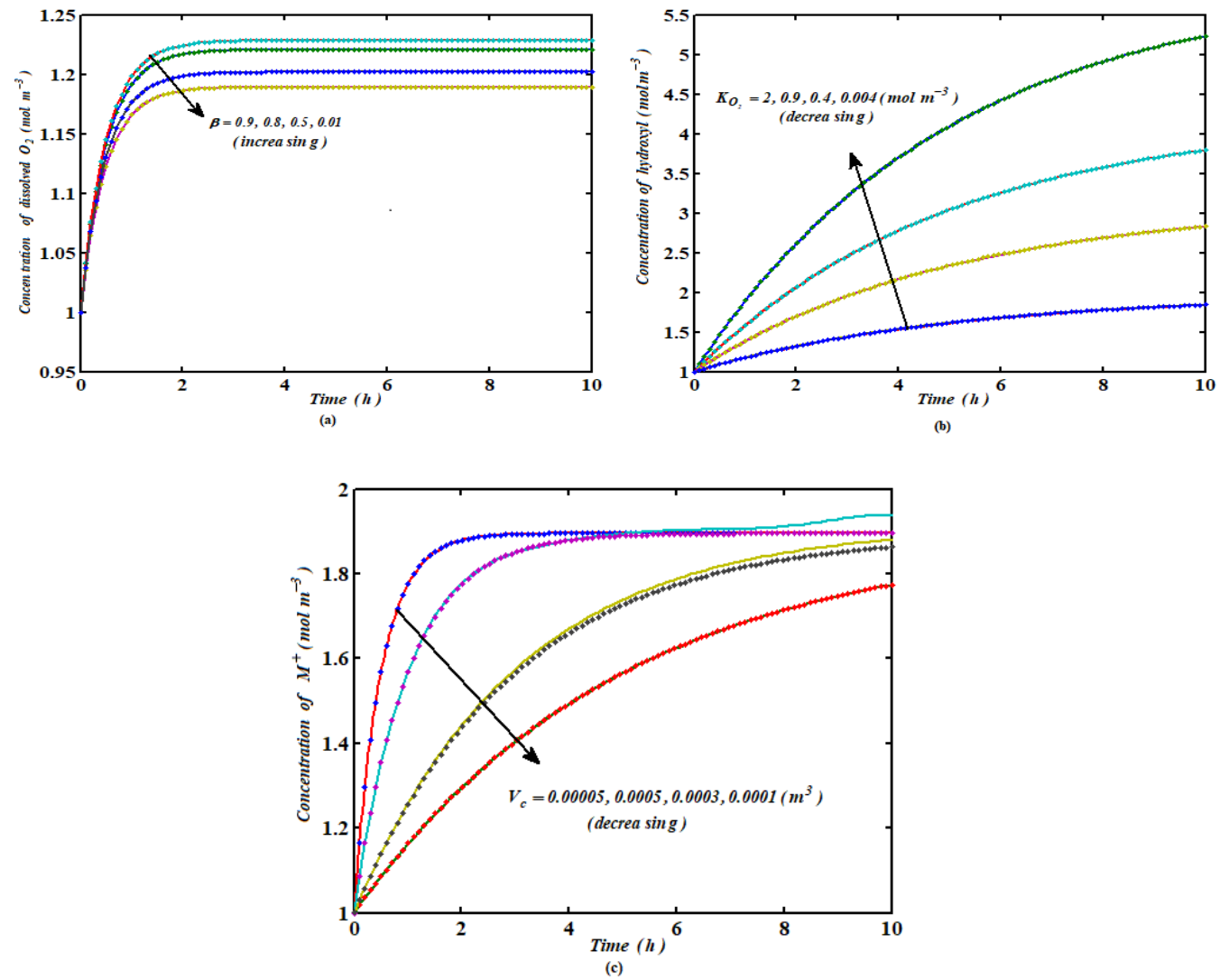

Fig.2 Comparison of analytical and numerical solutions of cathode compartment in Microbial fuel cell.

(a) Concentration of dissolved $\mathrm{O}_{2}$ versus time (Eqns.(38))

(b) Concentration of hydroxyl versus time (Eqn. (39))

(c) Concentration of $\mathrm{M}^{+}$versus time (Eqn. (40))

Solid lines represent the numerical simulation and the dotted lines represent the analytical solutions.

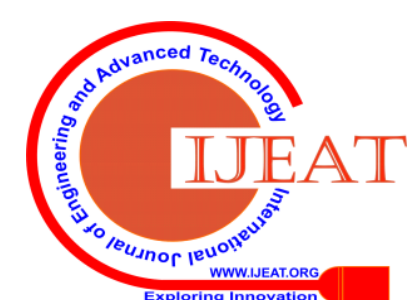



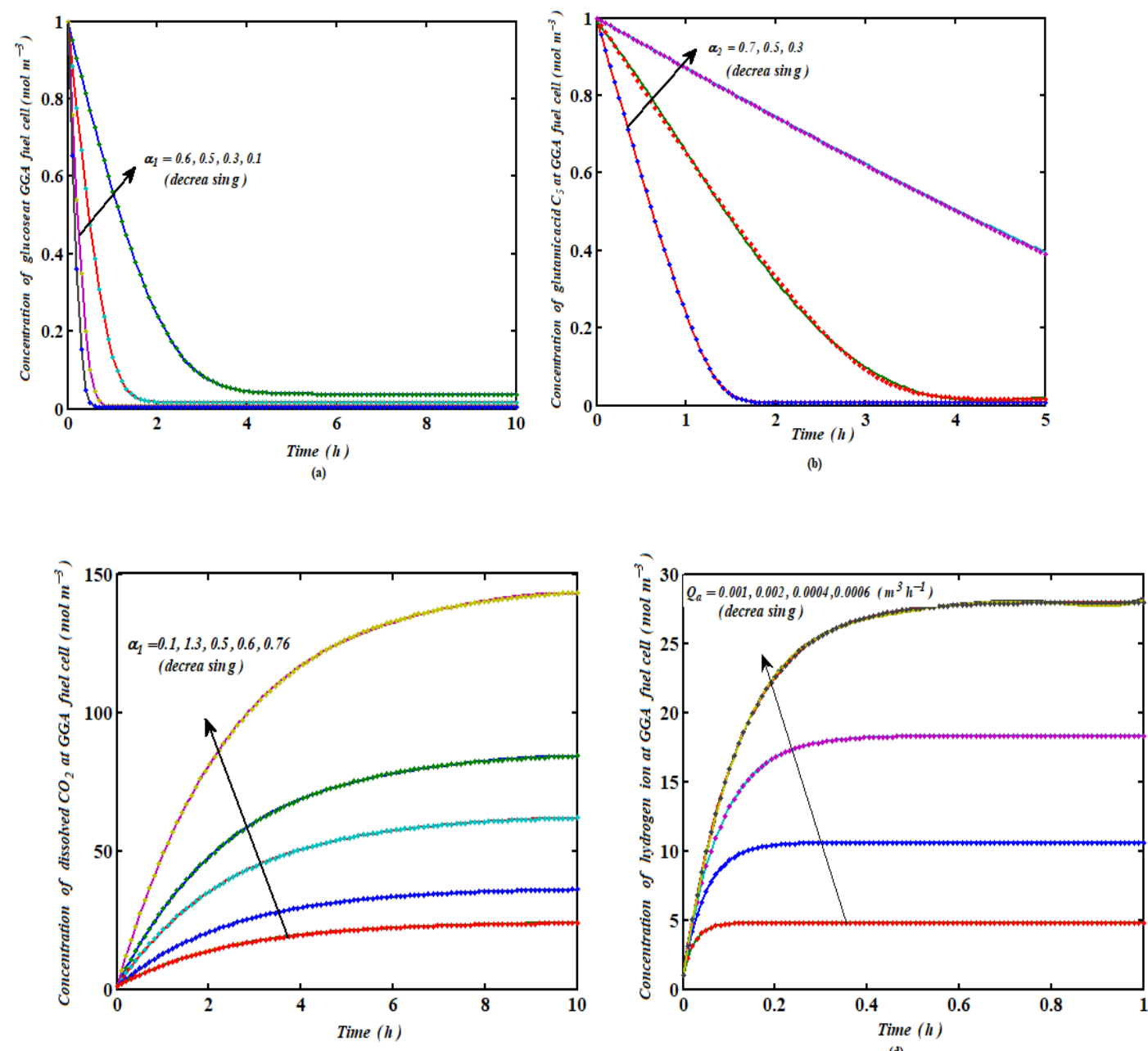

(c)

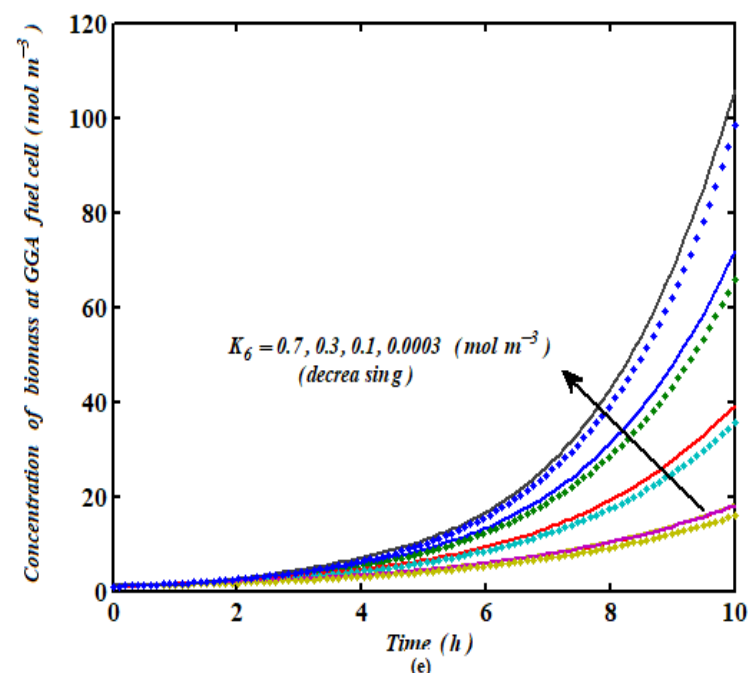

Fig.3 Comparison of analytical and numerical solutions of artificial waste water (glucose and glutamic acid.

(a) Concentration of glucose versus time (Eqns. (43-46))

(b) Concentration of glutamic acid versus time (Eqns. (49-51))

(c) Concentration of dissolved $\mathrm{CO}_{2}$ versus time (Eqn. (52))

(d) Concentration of hydrogen ion versus time (Eqn. (53))

(e) Concentration of biomass versus time (Eqn. (54)) 
Solid lines represent the numerical simulation and the dotted lines represent the analytical solutions.
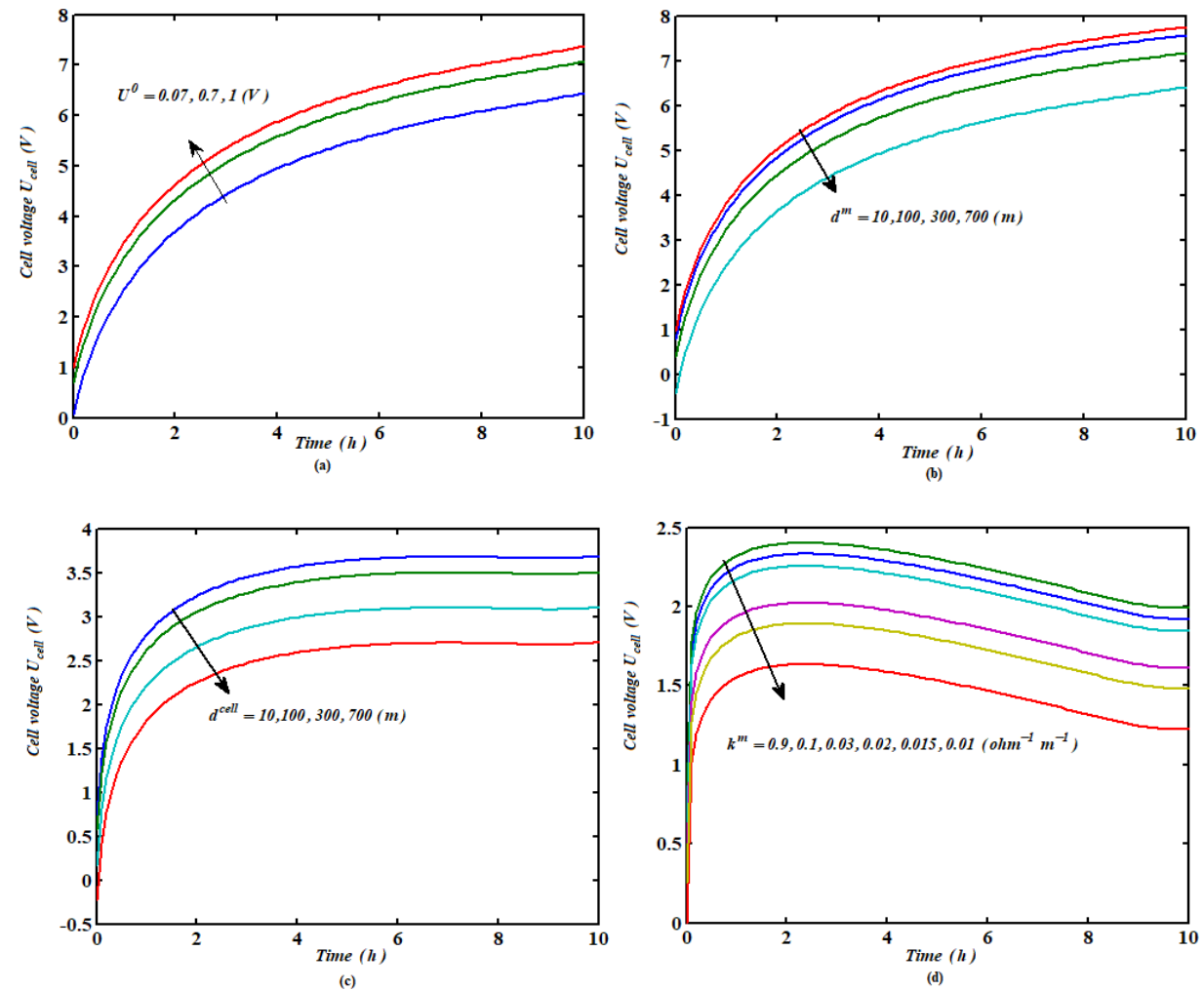

Fig. 4 plot of cell voltage $U_{\text {cell }}$ versus time for various values of parameters $U^{0}, d^{m}, d^{\text {cell }}$ and $k^{m}$ using Eqn. (59)
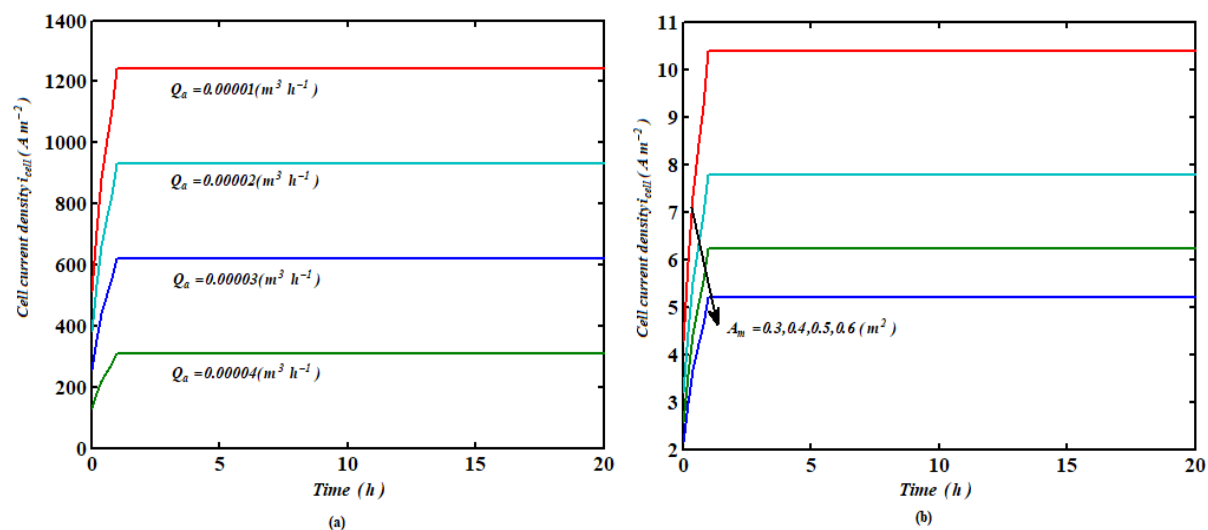

Fig. 5 plot of cell current density $i_{\text {cell }}$ versus time for various values of parameters $Q_{a}$ and $A_{m}$ using Eqn. (27)

\section{CONCLUSION}

The non-linear equations in two-chamber microbial fuel cells were solved analytically. The approximate analytical expression of concentration of acetate, dissolved carbon dioxide, hydrogen ion, biomass, dissolved oxygen, hydroxyl and cation $\mathrm{M}^{+}$in microbial fuel cell and GGA fuel cell for all experimental values of parameters are derived using the homotopy perturbation method. A satisfactory agreement with numerical simulation (Matlab program) is noted. These analytical expressions can be used to analyze the effect of various parameters such as decay constant, charge transfer coefficient of glucose and glutamic acid at anode and cathode, compartment. This theoretical result is also useful for the enzymatic microbial fuel cells.

\section{APPENDIX}

A. Approximate analytical solution of nonlinear Eqn. (6) using HPM for mass balances [5].

In this Appendix, we derive the general solution of the nonlinear reaction equation (6) using the new approach homotopy perturbation method. We begin by constructing the homotopy for Eqn. (34) as follows:

$$
\begin{aligned}
& (1-p)\left[\frac{d C_{\mathrm{CO}_{2}}}{d t}-\frac{Q_{a} C_{\mathrm{CO} 2}^{i n}}{V_{a}}+\frac{Q_{a} C_{\mathrm{CO} 2}}{V_{a}}-2 \frac{A_{m} k_{1}^{0} C_{A C}(t=0) X(t=0)}{V_{a}\left(K_{A C}+C_{A C}(t=0)\right)} e^{\left(\frac{\alpha F}{R T} \eta a(t=0)\right)}\right] \\
& p\left[\frac{d C_{\mathrm{CO} 2}}{d t}-\frac{Q_{a} C_{\mathrm{CO} 2}^{i n}}{V_{a}}+\frac{Q_{a} C_{\mathrm{CO} 2}}{V_{a}}-2 \frac{A_{m} k_{1}^{0} C_{A C} X}{V_{a}\left(K_{A C}+C_{A C}\right)} e^{\left(\frac{\alpha F}{R T} \eta a\right)}\right]=0
\end{aligned}
$$


The approximate solution of the Eq. (A1) is

$C_{\mathrm{CO}_{2}}(t)=C_{\mathrm{CO}_{2_{0}}}(t) p^{0}+C_{\mathrm{CO}_{21}}(t) P+C_{\mathrm{CO}_{22}}(t) P^{2}+\ldots$

Substituting equation (A2) into equation (A1) and equate the terms with identical power of $p^{0}$ we obtain

$p^{0}: \frac{d C_{\mathrm{CO}_{20}}}{d t}-\frac{Q_{a} C_{\mathrm{Co} 2}^{i n}}{V_{a}}+\frac{Q_{a} C_{\mathrm{CO} 2}}{V_{a}}-\frac{2 A_{n} k_{1}^{0} C_{A C . i n} X_{i n}}{V_{a}\left(K_{A C}+C_{A C, i n}\right)} e^{\left(\frac{\alpha F \eta_{a, i n}}{R T}\right)}=0$

with initial condition for Eqn. (A3) given by

$t=0, C_{C_{20}}=C_{C_{2 . i n}}$

Solving Eqn. (A3) with initial condition (A4), using first iteration we get:

$$
\begin{aligned}
& C_{\mathrm{CO}_{2}}(t)=C_{\mathrm{CO}_{20}}(t)=A \frac{Q_{a}}{V_{a}}+\left(C_{\mathrm{CO}_{2} . i n}-A \frac{Q_{a}}{V_{a}}\right) e^{-\frac{Q_{a} t}{V_{a}}} \text { where } \\
& A=\frac{Q_{a} C_{\mathrm{Co}_{2}}^{i n}+\frac{2 k_{1}^{0} A_{m} C_{A C . i n} X_{i n} e^{\left(\frac{\alpha F \eta_{a . i n}}{R T}\right)}}{V_{a}}}{V_{a}\left(K_{A C}+C_{A C . i n}\right)}
\end{aligned}
$$

\section{ACKNOWLEDGMENT}

The Authors are also thankful to Shri J. Ramachandran, Chancellor, Col. Dr. G. Thiruvasagam, Vice-Chancellor, Academy of Maritime Education and Training (AMET), Deemed to be University, Chennai, for their constant encouragement.

\section{REFERENCES}

1. S. Zhou, T. Schultz, M. Peglow, K. Sundmacher, Phys. Chem. Chem. Phys. 3, 2001

2. pp. 347-355.

3. Y. Zeng, N. Fujiwara, SI. Yamazaki, K. Tanimoto, P. Wu, J. Power Sources 185

4. 2008, pp. 95-103.

5. C. Picioreanu, I.M. Head, K.P. Katuri, M.C.M. van Loosdrecht, K. Scott,Water Res.

6. 41, 2007, 2921-2940.

7. 4. VB. Oliveira, M. Simoes , LF. Melo, AMFR Pinto, Energy 61, 2013,pp. 463-471.

8. 5. Y. Zeng , YF. Choo, BH. Kim , P. Wu , J Power Sources,195,2010, pp. 79-89.

9. 6. E. Dannys , T. Green , A. Wettlaufer, CMR. Madhurnathakam, A Elkamel, J Bioprocess Biotech 6: 267, 2016,pp. 1-8.

10. 7. JS. Newman, Electrochemical systems, 2nd edn. Prentice Hall, Englewood Cliffs, NJ,1991.

11. 8. J.H. He, Phys. Lett. A 350(1-2), 2006, pp. 87

12. 9. J.H. He, Chaos Solitons Fractals 26(3), 2005, pp. 827.

13. 10. J.H. He, Int. J. Mod. Phys. B, 20(10), 2006, pp. 1141.

14. 11. ST. Suganya, P. Balaganesan, L. Rajendran, Int J Recent Technology and Engineering, 8(4), 2019,pp. 5634-5640.

\section{AUTHORS PROFILE}

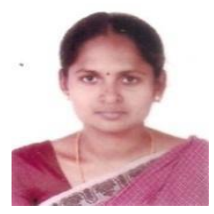

P. Jeyabarathi is an Assistant Professor in the Department of Mathematics, AMET Deemed to be University, Chennai 603112. She is also a part-time research scholar at Bharathidasan university Tiruchirappalli-620 024 and her research title is "A Mathematical model to solve nonlinear reaction diffusion equations using asymptotic methods". Her guide is Dr. M. Kannan, Assistant Professor in Mathematics, Governments Arts College, Ariyalur - 621 713, Tamil Nadu, India.

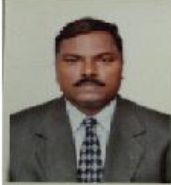

M. Kannan is an Assistant Professor in the Department of mathematics at Governments Arts College, Ariyalur - 621 713, Tamil Nadu, India. He has published several research papers in International and National journals. He completed more thanEight research students under his guidance.

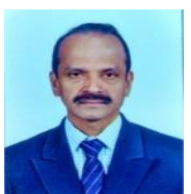

L. Rajendran is a Professor at the Department of Mathematics, Academy of Maritime Education and Training

(Deemed to be University), Chennai, India. He has published 110 papers in international/SCI journals and 100 papers in national journals. He has also written four books. He serves as a reviewer in many International Journals. He completed 6 research projects from various funding agencies in India. More than 35 students completed the Ph.D under his guidance. He visited Germany and Poland under INSA fellowships. 